\title{
Pattern Occupational Health Problems of building Construction Workers
}

\author{
Sunil Kumar ${ }^{1}$, Neelam Kotwal ${ }^{2}$, Monika Malhotra ${ }^{1}$ and Mohammad Sarwar Mir ${ }^{3}$ \\ ${ }^{1}$ MO Grade 1 ESIC Hospital Jammu. India \\ ${ }^{2}$ Former Medical Officer at Shri Mata Vaishno Devi Shrine Board, Jammu, India \\ ${ }^{3}$ Senior Resident, SKIMS, Soura, India
}

Submission: January 17, 2019; Published: April 09, 2019

*Corresponding author: Sunil Kumar, MO Grade 1 ESIC Hospital Jammu. India

Abstract

Background: Occupational risks have been classed as the tenth leading cause of morbidity and mortality.

Aim: The aim of this study is to understand the occupational health problems of building construction workers engaged at large construction.

Materials and methods: The cross-sectional study was conducted at a large scale building construction site. All workers $(\mathrm{N}=300)$ were enrolled as study subjects. Data was collected by the team consisting of investigators, doctors and social worker using a pre tested validated structured proforma.

Result: Among 300 workers only $30.0 \%$ used protective measure and $80.00 \%$ had suffered with at least one form of disease. Among them different diseases were found in following percentages including respiratory problems, musculo skelekal problems, dermatitis , and accidental injury.

Conclusion: Measures are needed to improve the work environment of construction workers by ensuring availability of protective gears, sanitation facilities at the sites along with an accessible, accountable occupational health services.

Keywords: Building Construction Workers; Occupational Health

\section{Introduction}

The construction industry is one of the world's major industries. It is an essential contributor to the process of development. Being an unorganized sector the workforce is at risk of developing safety and health related hazards at work. Construction workers in both are at a greater risk of developing certain health disorders and sickness than workers in many other industries.

They are exposed to multiple physical, chemical and biological agents, which make them vulnerable to various health problems that include-injuries, respiratory problems, dermatitis, musculo-skeletal disorders and gastro-intestinal diseases [1]. Due to ergonomic issues they are also vulnerable to degenerative disorders. Apart from this, in most of construction projects the workers employed are unorganized in nature and often not guided by the legislations made for the health and welfare of the workers and hence are not eligible for free or subsidized care $[2,3]$.

In the era of globalization construction is a fast growing industry and very little research has been done on the occupational health, hazards and psychosocial problems of these workers. In this context to understand the health problems of building construction workers and advocate public health policy measures, this study was conducted.

\section{Objective}

To study health problems of construction workers at a large building construction site.

\section{Material and Methods}

A cross sectional study was conducted at a large construction building site in april 2014. All the 300 construction workers working at the site in were selected. After a complete physical examination, data were recorded in a pre-designed structured questionnaire, providing a detailed job condition, personal and past medical history and the length of employment in the current job position. The duration of exposure was calculated as years in occupation. In addition, the subjects were asked about use of protective equipments and the type of personal protective equipment used.

\section{Statistical Analysis}

All collected data were checked and rechecked for omissions, inconsistencies and improbabilities. Data analysis were 
performed by Statistical Package for Social Science (SPSS), version-20.

Results

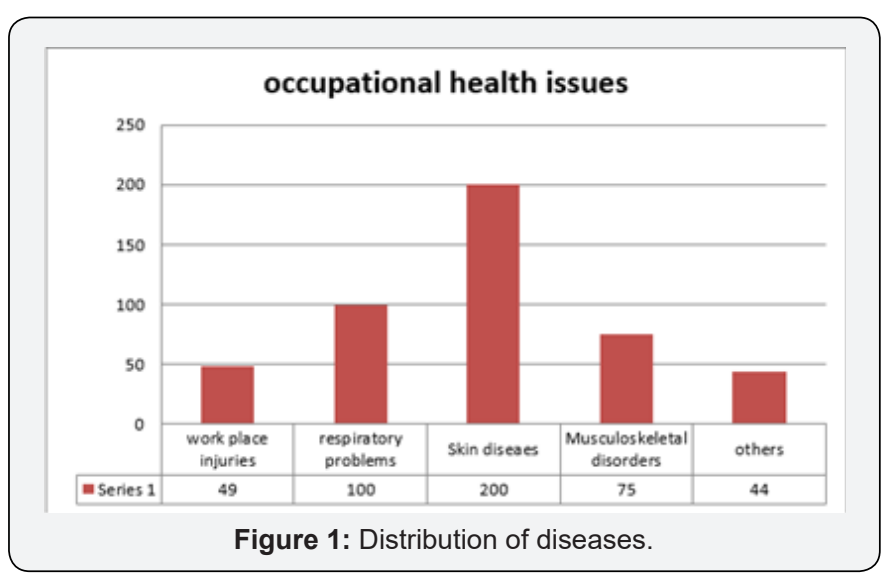

A total of three hundred workers were studied during the research period out of which 240 had suffered some health problems (Figure 1 \& Table 1).

Table 1: Protective measures

\begin{tabular}{|c|c|c|}
\hline $\begin{array}{c}\text { Protective Measures (boots, goves, } \\
\text { apron, helmets etc) }\end{array}$ & Frequency & Percentage \\
\hline Available or used & 90 & $30.00 \%$ \\
\hline Not available or not used & 210 & $70.00 \%$ \\
\hline
\end{tabular}

\section{Discussion}

Rapid urbanization and industrialization have imposed a huge load of construction works worldwide, which creates different social, cultural and health impact. The construction workers are exposed to multiple risks at working and living places, they are exposed to physical, chemical, biological, ergonomic hazards and environmental and psycho social risks. In the current study among three hundred construction workers $75 \%$ of them have at least one form of disease. Out of all skin diseases, were the most commonest (83.33\%) followed by respiratory problems (41.7\%) and musculoskeletal disorders (31.25\%).
The results are consistent with findings of other studies [1,2]. In the current study only30.0\% workers had opportunity to use any form protective measure. The prolonged exposure to construction materials for years without almost no protective measures may be cause of this high rate of contact dermatitis. The construction workers are a group of less skilled workers who start the occupation without previous training; this situation facilitates the emergence of occupational dermatitis. More over in this study almost all workers are belong to low socio-economics class, they have limited excess to healthcare, lack of sufficient health education. All these factors produce a cumulative affect to their health which can be prevented by providing improved work place, protective means, health education, adequate health services and improving professional skills $[4,5]$.

\section{Conclusion}

Measures are needed to improve the work environment of building construction workers by ensuring availability of protective gears, good living conditions and sanitation facilities at the sites along with an accessible, accountable occupational health services. A system of health recording and routine surveillance among workers should be implemented.

\section{References}

1. Mohammad SM, Ruksana H, Mohammad A, Ghulam MM (2018) Occupational Health Problems of Construction Workers in Valley of Kashmir. Res Med Eng Sci 4(1).

2. Mubashar Mashqoor (2017) Occupational Skin Diseases in construction workers at a large construction site. EJPMR 4(12): 383-385.

3. Jayakrishnan $\mathrm{T}$ (2013) Occupational health problems of construction workers in India. int J Med public health 3: 225-9.

4. Kulkarni GK (2007) Construction industry:more needs to be done. Indian J occup Environ Med 11(1): 1-2.

5. Sarwar (2017) Occupational Contact dermatitis among construction workers. WJPMR 3(11): 136-138.

\section{Your next submission with Juniper Publishers} will reach you the below assets

- Quality Editorial service

- Swift Peer Review

- Reprints availability

- E-prints Service

- Manuscript Podcast for convenient understanding

- Global attainment for your research

- Manuscript accessibility in different formats

( Pdf, E-pub, Full Text, Audio)

- Unceasing customer service

Track the below URL for one-step submission https://juniperpublishers.com/online-submission.php 